\title{
Protective Of the Presidency
}

By Peter M. Shane and Reed Hundt

Sunday, September 11, 2005

Now that John Roberts has been nominated for the post of chief justice, there is growing sentiment among senators -- especially Democrats -- that President Bush's choice should be treated as something of a "gimme." After all, from the liberal point of view, some argue, how could he be worse than the late Chief Justice William Rehnquist?

Well, based on Roberts's views while he was an executive branch lawyer and on his recent vote in the case of Hamdan v. Rumsfeld -- which held that military commissions may determine whether military captives are prisoners of war or enemy combatants -- there is every reason to suspect that as chief justice, Roberts could well move the Supreme Court in a much more conservative direction on an all-important but easily overlooked set of issues: constitutional checks and balances as applied to the president.

On relationships among the three branches of our federal government, Rehnquist was a moderate, often espousing classic mainstream views. Of critical importance were two majority opinions he wrote in 1988.

One, Morrison v. Olson, was the decision that upheld the independent-counsel law. The issue was whether the Constitution permitted Congress to empower courts in certain high-profile cases to appoint special prosecutors who would be free from the president's direct control.

Over a strident dissent by Justice Antonin Scalia, Rehnquist said that, yes, this was up to Congress. Whether or not using an independent counsel was a good idea, the system that Congress created did not prevent the president from discharging his constitutionally vested responsibilities. Therefore, the Constitution allows Congress to check the president in this way.

The second impressive Rehnquist statement that year was his majority opinion in Webster v. Doe, in which the court held that a CIA clerk was entitled to judicial review of the revocation of a security clearance because of his homosexuality. Over a sarcastic Scalia dissent, Rehnquist held that the clerk was entitled at least to the benefit of a longtime presumption that Congress wants federal courts to decide constitutional challenges in federal cases involving individual rights. The court would not lightly accept executive immunity from constitutional review.

Among the more recent examples

of Rehnquist's moderation on the question of executive power was his November 2004 vote for the plurality opinion

in Hamdan v. Rumsfeld. That case affirmed that the president has authority granted by Congress to hold "enemy combatants" who are apprehended during our military operations in Afghanistan, even if the combatants are U.S. citizens. The court insisted, however, that U.S. citizens are entitled to administrative due process in determining their status as "enemy combatants" and may challenge in federal courts the legality of their detention.

The Bush administration had argued unsuccessfully that the authority to hold enemy combatants was inherently an executive function under the Constitution and not subject to Congress's regulation or to judicial review. Justice Clarence Thomas, in a pro-administration dissent, would have ruled that the decision to hold a U.S. citizen indefinitely as an enemy combatant "falls squarely within" the president's war powers and could not be examined by the federal judiciary.

Against this background, it would

be worrisome if Rehnquist's successor were less vigilant with regard to the ambitions of the executive branch. Yet, as a White House lawyer and as a judge, John Roberts has seemed comfortable with legal claims suggestive of the imperial presidency. 
He expressed doubts, for example, about whether Congress acts constitutionally in creating independent agencies, even though such agencies have been part of our governmental system for well over a century. He expressed concern about the possible threat to executive privilege embodied in the Presidential Records Act, which requires most presidential documents to be made public 12 years after a president leaves office.

Most recently, he voted in favor of the argument that the executive could deny prisoner-of-war status to a military captive based solely on the determination by a military commission that the individual deserved a lessprotected "enemy combatant" status.

An all-but-impregnable presidency is part of the core legal faith of the Bush administration, and it is hard to imagine any set of constitutional issues more likely to be critical over the coming decades.

One-party government during a period

of national anxiety over terrorism is a fertile breeding ground for presidential overreaching.

With regard to issues surrounding presidential accountability to law, Americans should demand a nominee at least as thoughtful and prudent as the late chief. It is not clear whether John Roberts is that nominee.

Peter M. Shane teaches law at Ohio State University. Reed Hundt was chairman of the Federal Communications Commission from 1993 to 1997.

(C) 2005 The Washington Post Company 